\section{Rough Bluegrass Germination Varies with Temperature and Cultivar/Seed Lot}

\author{
Chunhua Liu' ${ }^{1}$, James J. Camberato ${ }^{2}$, S. Bruce Martin ${ }^{3}$, and \\ Amy V. Turner ${ }^{4}$ \\ Clemson University, Pee Dee Research and Education Center, 2200 Pocket \\ Road, Florence, SC 29506
}

\section{Additional index words. Cynodon sp., Poa trivialis, overseeding}

\begin{abstract}
Rough bluegrass (Poa trivialis L.) is being utilized more frequently to overseed bermudagrass [Cynodon dactylon (L.) Pers. $x$ C . transvaalensis Burtt-Davy] putting greens and rapid seed germination is necessary for successful establishment. Cultivar and seed lot differences in germination rate and sensitivity to cold may exist. Germination of 10 rough bluegrass cultivars/seed lots was examined in growth chambers at 12hour day/12-hour night temperatures of $25 / 15,20 / 10,15 / 5$, and $10 / 0{ }^{\circ} \mathrm{C}$, and on a bermudagrass putting green at three overseeding dates. Differences in germination among cultivars and seed lots were minimal at $25 / 15$ or $20 / 10{ }^{\circ} \mathrm{C}$, but substantial at lower temperatures. When seeded on the bermudagrass putting green, differences in germination among cultivars/seed lots were greater at the last seeding date (average daily max./ min. of $16 / 2.7^{\circ} \mathrm{C}$ ), than at the first seeding dates (average daily max./min. of $21 / 6.1{ }^{\circ} \mathrm{C}$ ). Use of blends of several cultivars or seed lots is suggested to ensure the successful establishment of rough bluegrass when overseeding at low temperatures.
\end{abstract}

Overseeding cool-season turfgrasses on bermudagrass putting greens in the fall is a common practice in the southeastern United States (Johnson, 1994). Overseeding is necessary to provide a dense green turf during winter months and a uniform playing surface. It also reduces thinning of turf from equipment and foot traffic and decreases weed invasion during winter dormancy (Mazur, 1984). Perennial ryegrass (Lolium perenne L.) has been the dominant turfgrass species used for overseeding because of its rapid establishment, wear tolerance, and competitiveness with annual bluegrass (Poa annua L.) (Dudeck and McCarty, 1989). However, perennial ryegrass may compete excessively with bermudagrass, thus slowing the spring transition (Johnson, 1988).

Recently, there has been a trend toward the use of rough bluegrass for overseeding bermudagrass putting greens (Johnson, 1994). This grass has been utilized for years in blends with perennial ryegrass (Batten et al., 1981; Ward et al., 1974), but superintendents are increasingly overseeding greens with

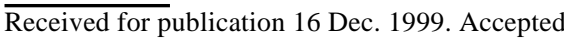
for publication 17 July, 2000. Technical contribution no. 4613 of the South Carolina Agriculture and Forestry Research System, Clemson. The cost of publishing this paper was defrayed in part by the payment of page charges. Under postal regulations, this paper therefore must be marked advertisement solely to indicate this fact.

${ }^{1}$ Former Postdoctoral Scientist.

${ }^{2}$ Associate Professor, Crop and Soil Environmental Science Dept. To whom requests for reprints should be addressed E-mail: jcmbrt@ clemson.edu. ${ }^{3}$ Associate Professor, Dept. of Plant Pathology and Physiology.

${ }^{4}$ Agriculture/Animal Associate II. temperature. Little information exists on the extent of these differences. The objectives of this research were to investigate the effects of temperature on rough bluegrass germination and differences in germination among cultivars/seed lots.

\section{Materials and Methods}

Studies were conducted in growth chambers and on a 'Tifdwarf' bermudagrass putting green located at the Pee Dee Research and Education Center, Clemson Univ., Florence, S.C.

Chamber study. Following storage at $4{ }^{\circ} \mathrm{C}$, 25 seeds of 10 rough bluegrass cultivars and seed lots (Table 1) were placed on filter paper saturated with deionized water in each $8-\mathrm{cm}$ diameter petri plate and maintained in growth chambers with $12 \mathrm{~h}$ day/ $12 \mathrm{~h}$ night temperatures of $25 / 15,20 / 10,15 / 5$, and $10 / 0{ }^{\circ} \mathrm{C}$. Irradiance was maintained with fluorescent lamps at $20 \mathrm{~W} \cdot \mathrm{m}^{-2}$ during the day. Three replications of each cultivar/seed lot were used per chamber. Seed germination was determined $7,10,14,17,21,24$, and $28 \mathrm{~d}$ after seeding. The entire study was repeated three times (runs), 4 Dec. 1998-1 Jan. 1999, 8 Jan.-2 Feb. 1999, and 19 Feb.-3 Mar. 1999. Experimental design was a split-plot with temperature regime as the main-plot factor and cultivars/seed lots as the split-plot factor, with runs being used as blocks.

Field study. To evaluate different temperature regimes under field conditions, the same cultivars/seed lots were seeded 23 Oct. and 6 Nov. 1998 and 4 Jan. 1999. Average daylengths during these studies were $10 \mathrm{~h} 40$ $\mathrm{min}, 10 \mathrm{~h} 18 \mathrm{~min}$, and $10 \mathrm{~h} 10 \mathrm{~min}$. Fifty seeds of the 10 rough bluegrass cultivars/seed lots were seeded randomly within $10-\mathrm{cm}$ diameter circles on a 'Tifdwarf' bermudagrass green. Experimental design was a split-plot with seeding date as the main-plot factor and cultivars/seed lots as the split-plot factor with four replications. Seed germination was recorded $7,10,14,17,21,24$, and $28 \mathrm{~d}$ after seeding. Plots were irrigated or received rain daily, providing favorable moisture for seed germination, and mowed at $0.36 \mathrm{~cm}$ every other day, except on days when germination was determined. Daily maximum and minimum temperatures were recorded.

Table 1. Rough bluegrass cultivars/seed lots used to examine temperature effects on germination and germination rate in growth chamber and field studies.

\begin{tabular}{lcccc}
\hline \hline Cultivar $^{z}$ & Seed lot & State of origin & Testing date & Germination $^{y}(\%)$ \\
\hline Colt & U17-5-PT102 & Ore. & Sept. 1995 & 85 \\
Cypress A & J5-5-CY4-191 & Ore. & Sept. 1995 & 85 \\
Cypress B & J11-6-CY34-178 & Ore. & Aug. 1996 & 94 \\
Cypress C & J11-8-CY5-228 & Ore. & Sept. 1998 & 90 \\
Darkhorse & U17-5-PT104 & Wash. & Sept. 1995 & NR $^{\mathrm{x}}$ \\
Laser A & J6-5-LA705 & Ore. & Aug. 1995 & 85 \\
Laser B & J6-7-LA712 & Ore. & Aug. 1997 & NR \\
Winterplay A & U17-5-PT101 & Wash. & July 1995 & 85 \\
Winterplay B & J7-7-WP52 & Ore. & Aug. 1997 & NR \\
Winterplay C & J7-8-WP70 & Ore. & Sept. 1998 & 92
\end{tabular}

${ }^{2}$ Mention of a cultivar or seed lot does not imply endorsement by Clemson Univ.

${ }^{y}$ As listed on bag tag. Value obtained using methods prescribed by Association of Official Seed Analysts (1993).

${ }^{\mathrm{x}} \mathrm{NR}=$ not recorded. 
Data analysis. Germination rate was calculated by the method of Maguire (1962), which sums the number of new seedlings at each count divided by the number of days to each count. Larger numbers indicate faster germination. All data were subjected to analysis of variance using the Statistical Analysis System (SAS Institute, 1985). Relevant statistical models are listed in Table 2. Sums of squares for temperature $\times$ cultivar and temperature $\times$ seeding date interactions were partitioned to determine variation among cultivars within different temperature regimes or seeding dates. The Duncan's new multiple range test at $P \leq 0.05$ was used for mean separation.

\section{Results and Discussion}

Both chamber and field studies showed significant differences in seed germination and germination rate among the four temperature regimes or three overseeding dates, and significant differences among cultivars and seed lots (Table 2).

Rough bluegrass germinated better and faster at warmer temperatures in growth chambers and with earlier seeding dates on the bermudagrass green. Germination exceeded $80 \%$ on day 7 with temperatures of $25^{\circ} \mathrm{C}$ day/ $15{ }^{\circ} \mathrm{C}$ night (Fig. 1A). However, at $10 / 0{ }^{\circ} \mathrm{C}$, germination was delayed for $\approx 2$ weeks and the final germination percentage never reached $70 \%$ (Fig. 1D). Germination rate increased sharply with increasing temperature from 10/ $0{ }^{\circ} \mathrm{C}$ to $15 / 5^{\circ} \mathrm{C}$ (Table 3 ). Further, but more gradual, increases in the germination rate occurred with higher temperature regimes.

On the bermudagrass green, the final germination percentage of the first seeding date (23 Oct.) was $\approx 40 \% 28 \mathrm{~d}$ after seeding (Fig. $2 \mathrm{~A})$. However, at the last seeding date (4 Jan.) germination was $<30 \%$ (Fig. 2C). The average maximum and minimum temperatures $\left(21\right.$ and $\left.6.1^{\circ} \mathrm{C}\right)$ during the first two overseeding periods were warmer than those (16 and $\left.2.7^{\circ} \mathrm{C}\right)$ in the third overseeding period. Germination rates during the coldest overseeding period were markedly less than those rates during the first and second overseeding (Table 3 ).

Germination values listed on the seed bag certification tag by the Oregon State Univ. Seed Laboratory (e.g., those listed in Table 1) are obtained at $21 \mathrm{~d}$ at $16 \mathrm{~h}$ day/8 h night temperatures of $30 / 20{ }^{\circ} \mathrm{C}$ (Association of Official Seed Analysts, 1993). Germination values obtained in our study with warm temperatures in the growth chamber (Fig. $1 \mathrm{~A}$ and B) were equivalent to or greater than those listed. However, with suboptimal conditions, such as those encountered on the overseeded green (Fig. 2) or at low temperatures (Fig. 1, $\mathrm{C}$ and $\mathrm{D})$, germination was considerably less than the listed value. Germination testing at low temperature, such as is used to evaluate seedling vigor for some agronomic crops (Association of Official Seed Analysts, 1983), may better reflect rough bluegrass germination under stressful conditions.

Our results with cultivars of rough bluegrass are similar to those of Williams (1983), who studied the germination of a grassland population of rough bluegrass. Williams induced optimum germination by alternating $20^{\circ} \mathrm{C}$ with 9 to $12^{\circ} \mathrm{C}$. Constant temperatures below 5 to $7{ }^{\circ} \mathrm{C}$ prevent rough bluegrass germination (Beard and Almodares, 1980; Froud-Williams et al., 1986). Budd (1970) found that temperatures below $10^{\circ} \mathrm{C}$ reduced and delayed germination of rough bluegrass seed populations in grasslands. Therefore, growth chamber temperature regimes of $15 /$ 5 and $10 / 0{ }^{\circ} \mathrm{C}$ and the $16 / 2.7^{\circ} \mathrm{C}$ encountered at the last seeding date would be expected to slow germination.
Differences in germination and germination rate among the 10 rough bluegrass cultivars and seed lots were minimal at warm temperatures (Fig. $1 \mathrm{~A}$ and B, Table 3 ) and on the green at early seeding dates (Fig. $2 \mathrm{~A}$ and $\mathrm{B}$, Table 3). However, at low temperatures in the growth chamber (Fig. $1 \mathrm{C}$ and D, Table 3) and at the last seeding date (Fig. 2C, Table 3), the differences were large. For example, germination at $28 \mathrm{~d}$ ranged from $36 \%$ to $68 \%$ at $10 / 0{ }^{\circ} \mathrm{C}$ in the growth chamber, and from $14 \%$ to $34 \%$ on the bermudagrass green at the last seeding date (Table 4). Germination rate ranged from 0.5 to 0.9 at $10 / 0^{\circ} \mathrm{C}$ and from 0.3 to 0.9 for the last seeding date (Table 3 ). Not only did differences occur among cultivars, but there were also differences among seed lots of the same cultivar. Germination and germination rate of one of the three seed lots of 'Winterplay' and of 'Cypress' examined were substantially lower than those of the other two seed lots (Tables 3 and 4).

Our results showed that germination and germination rate of rough bluegrass cultivars and seed lots varied much more at cold temperatures than at warm temperatures. Differences among seed lots of a particular cultivar may be due to the tendency of seed fields to shatter as maturity nears. To avoid loss of the seed crop, growers may harvest early, but this practice may lead to inconsistency in seed maturity (Hurley and Funk, 1985). In Kentucky bluegrass (Poa pratensis L.), seed dormancy and sensitivity to germination conditions declined with maturity (Delouche, 1958). Until a screening procedure is developed to identify cold-sensitive cultivars and seed lots, use of blends of several cultivars is suggested to ensure establishment of rough bluegrass when overseeding. Superintendents may purchase blends of cultivars, or purchase cultivars separately and "blend" them on the greens. Early seeding dates, when

Table 2. Analysis of variance of effects of cultivar/seed lot and temperature on rough bluegrass germination and germination rate in growth chamber and field studies

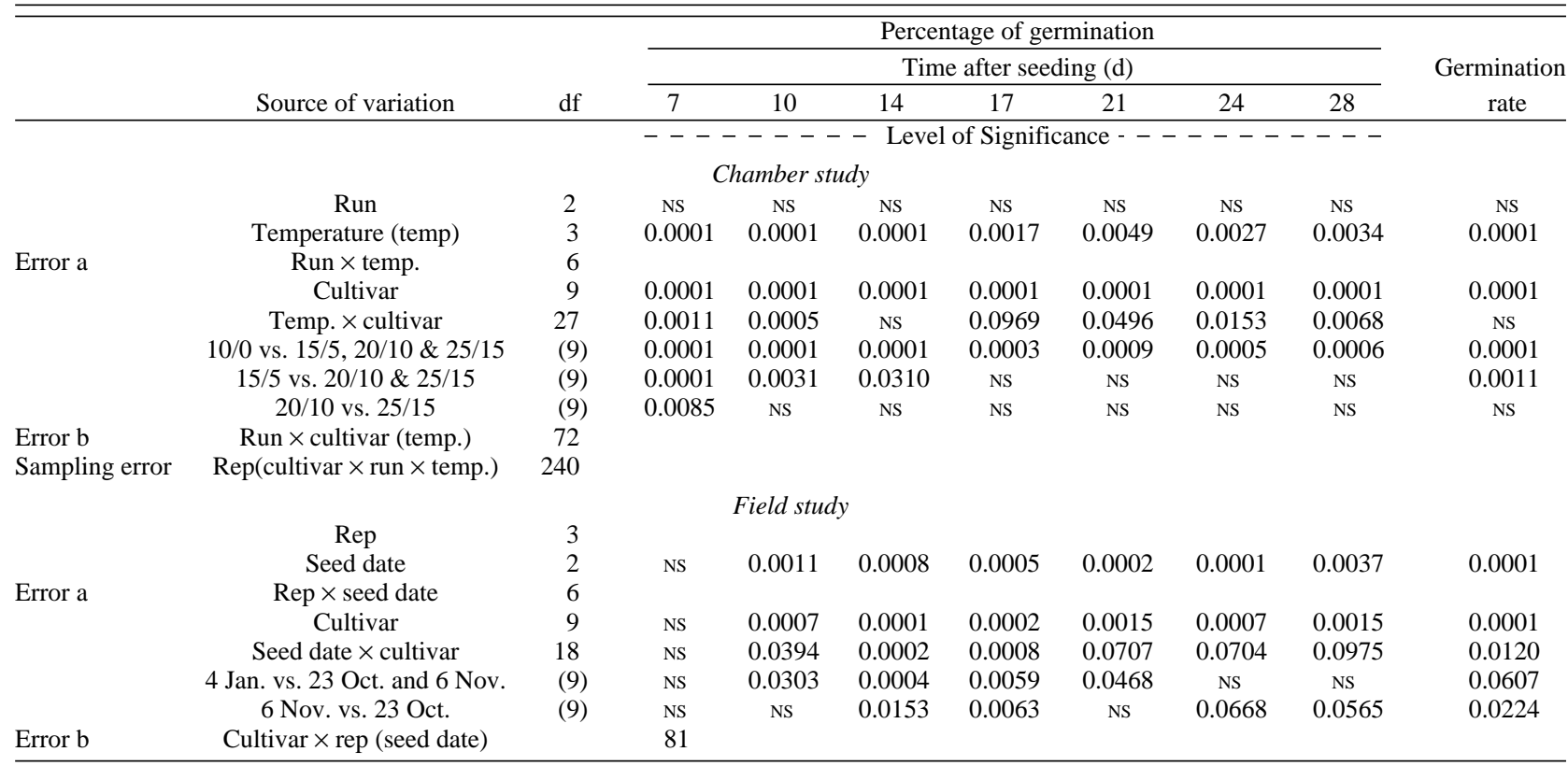


temperatures are generally high $\left(20\right.$ to $\left.25^{\circ} \mathrm{C}\right)$, and multiple seed applications are other techniques used to improve establishment of cold-sensitive cultivars and seed lots. If superintendents decide to seed in the early fall to take advantage of warm temperatures, other factors, such as competition with bermudagrass and Poa annua management with fenarimol $[\alpha(2$-chlorophenyl)- $\alpha-(4-$ chlorophenyl)-5-pyrimidinemethanol], may complicate establishment (Johnson, 1994). Also, the potential for disease development on young seedlings, particularly dampingoff caused by Pythium and Rhizoctonia sp., is high when temperatures are warm and moisture is adequate for germination. Furthermore, fungicide phytotoxicity can complicate disease management (Martin, 1996). These factors must also be considered.

\section{Literature Cited}

Association of Official Seed Analysts. 1983. Seed vigor testing handbook. No. 32.
Association of Official Seed Analysts. 1993. Rules for testing seeds. J. Seed Tech. 16:1-113.

Batten, S.M., J.B. Beard, D. Johns, A. Almodares, and J. Eckhardt. 1981. Characterizations of cool season turfgrasses for winter overseeding of dormant bermudagrass, p. 83-94. In: R.W. Sheard (ed.). Proc. $4^{\text {th }}$ Intl. Turfgrass Res. Conf., Guelph, Ont., Canada. 19-23 July 1981. Intl. Turfgrass Soc., Ontario Agr. Coll., Univ. of Guelph.

Beard, J.B. and A. Almodares. 1980. Minimum temperature requirements for seed germination of turfgrasses, p. 13-15. In: Texas Turfgrass Research-1978-79. Feb. 1980.

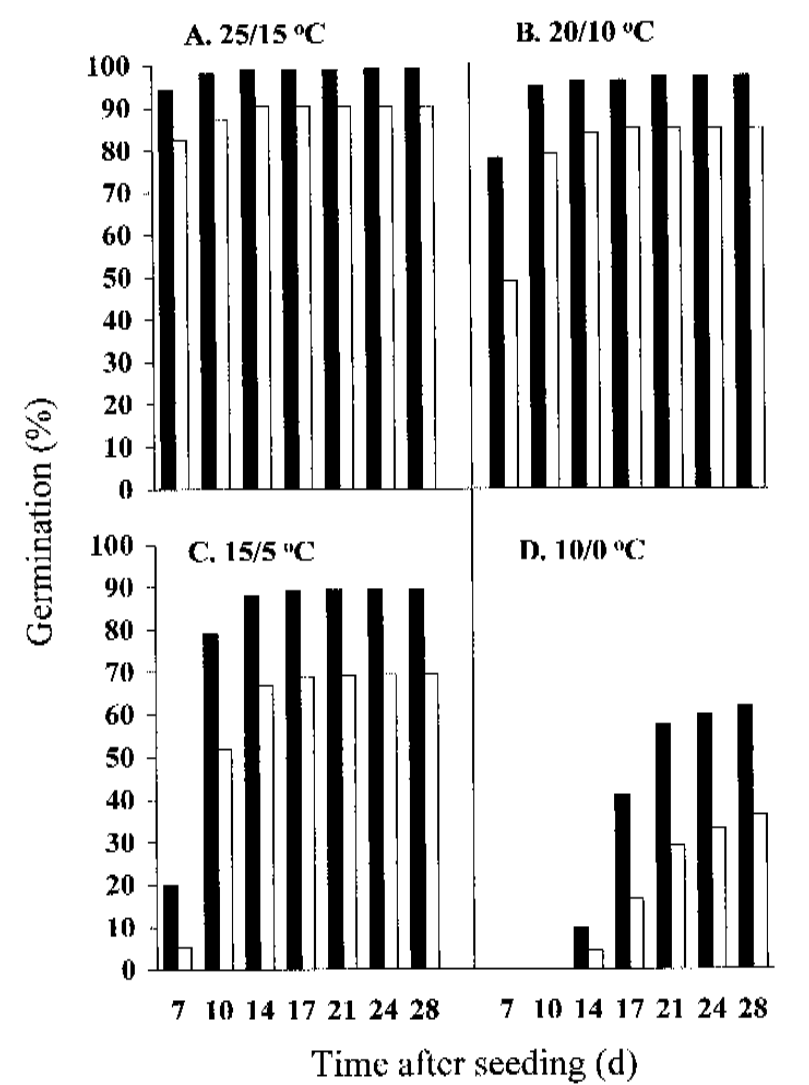

Fig. 1. Germination in growth chambers of two rough bluegrass cultivars seeded in petri plates at four temperature regimes. 'Cypress' A ( $\mathbf{\square})$ was one of the fastest to germinate and 'Winterplay' B ( $\square$ ) one of the slowest. The other eight cultivars or seed lots are not depicted, but generally fell within these extremes.
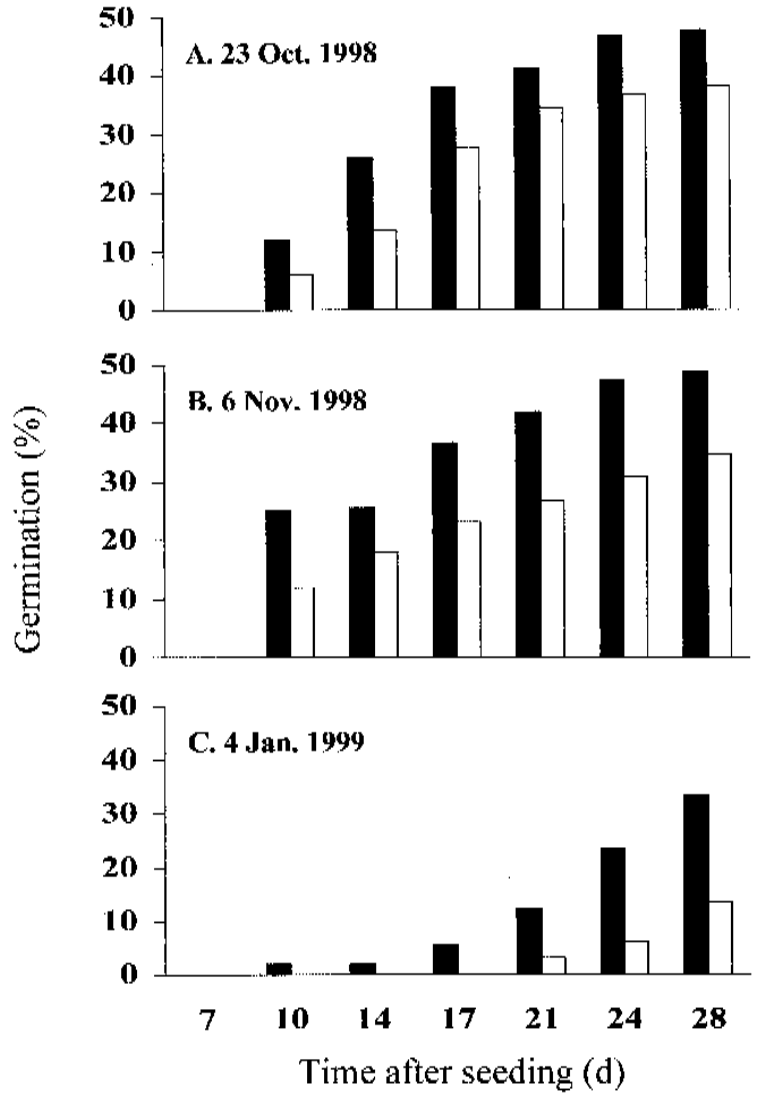

Fig. 2. Germination on a 'Tifdwarf' bermudagrass putting green of two cultivars of rough bluegrass seeded on three dates. 'Cypress' A ( $\mathbf{\square})$ was one of the fastest to germinate and 'Winterplay' B ( $\square$ ) one of the slowest. The other eight cultivars or seed lots are not depicted, but generally fell within these extremes.
Table 3. Effects of temperature regime in growth chambers and of seeding date on a 'Tifdwarf' bermudagrass putting green on germination rates of 10 rough bluegrass cultivars/seed lots.

\begin{tabular}{|c|c|c|c|c|c|c|c|}
\hline \multirow[b]{3}{*}{ Cultivar } & \multicolumn{7}{|c|}{ Germination rate ${ }^{\mathrm{z}}$} \\
\hline & \multicolumn{4}{|c|}{ Growth chamber temperature regime, $\max / \min { }^{\circ} \mathrm{C}$} & \multicolumn{3}{|c|}{ Field seeding date } \\
\hline & $10 / 0$ & $15 / 5$ & $20 / 10$ & $25 / 15$ & 23 Oct. & 6 Nov. & 4 Jan. \\
\hline Colt & $0.9 \mathrm{a}^{\mathrm{y}}$ & $2.2 \mathrm{ab}$ & $3.1 \mathrm{ab}$ & $3.4 \mathrm{ab}$ & $1.6 \mathrm{a}$ & $2.2 \mathrm{a}$ & $0.8 \mathrm{ab}$ \\
\hline Cypress A & $0.9 \mathrm{a}$ & $2.4 \mathrm{a}$ & $3.2 \mathrm{a}$ & $3.5 \mathrm{a}$ & $1.6 \mathrm{a}$ & $1.9 \mathrm{a}-\mathrm{c}$ & $0.7 \mathrm{ab}$ \\
\hline Cypress B & $0.6 \mathrm{c}$ & $1.9 \mathrm{~b}-\mathrm{d}$ & $2.9 \mathrm{bc}$ & $3.2 \mathrm{bc}$ & $1.4 \mathrm{ab}$ & $2.0 \mathrm{ab}$ & $0.5 \mathrm{bc}$ \\
\hline Cypress C & $0.8 \mathrm{a}$ & $2.1 \mathrm{a}-\mathrm{c}$ & $2.9 \mathrm{bc}$ & $3.1 \mathrm{c}$ & $1.6 \mathrm{a}$ & $1.8 \mathrm{a}-\mathrm{c}$ & $0.7 \mathrm{ab}$ \\
\hline Darkhorse & $0.9 \mathrm{a}$ & $2.3 \mathrm{a}$ & $3.2 \mathrm{ab}$ & $3.5 \mathrm{a}$ & $1.3 \mathrm{~b}$ & $1.6 \mathrm{~cd}$ & $0.7 \mathrm{ab}$ \\
\hline Laser A & $0.8 \mathrm{a}$ & $1.9 \mathrm{~b}-\mathrm{d}$ & $2.8 \mathrm{c}$ & $3.3 \mathrm{a}-\mathrm{c}$ & $1.6 \mathrm{a}$ & $1.8 \mathrm{a}-\mathrm{c}$ & $0.7 \mathrm{ab}$ \\
\hline Laser B & $0.8 \mathrm{a}$ & $2.1 \mathrm{a}-\mathrm{c}$ & $2.9 \mathrm{bc}$ & $3.0 \mathrm{c}$ & $1.4 \mathrm{ab}$ & $1.2 \mathrm{de}$ & $0.6 \mathrm{a}-\mathrm{c}$ \\
\hline Winterplay A & $0.6 \mathrm{bc}$ & $1.9 \mathrm{~cd}$ & $2.6 \mathrm{c}$ & $3.2 \mathrm{bc}$ & $1.4 \mathrm{ab}$ & $1.7 \mathrm{bc}$ & $0.9 \mathrm{a}$ \\
\hline Winterplay B & $0.5 \mathrm{c}$ & $1.7 \mathrm{~d}$ & $2.6 \mathrm{c}$ & $3.1 \mathrm{c}$ & $1.2 \mathrm{~b}$ & $1.1 \mathrm{e}$ & $0.3 \mathrm{c}$ \\
\hline Winterplay C & $0.8 \mathrm{ab}$ & $2.1 \mathrm{a}-\mathrm{c}$ & $2.8 \mathrm{c}$ & $3.4 \mathrm{ab}$ & $1.5 \mathrm{ab}$ & $1.6 \mathrm{~cd}$ & $0.5 \mathrm{bc}$ \\
\hline Mean & 0.8 & 2.1 & 2.9 & 3.3 & 1.5 & 1.7 & 0.6 \\
\hline
\end{tabular}

${ }^{2}$ Rate $=\sum\left[\left(\right.\right.$ no. new seedlings $\left.\div \mathrm{t}_{1}\right)+\left(\right.$ no. new seedlings $\left.\left.\div \mathrm{t}_{2}\right)+\ldots.\right]$.

'Mean separation within columns by Duncan's multiple range test, $P \leq 0.05$ level.
Table 4. Germination of 10 rough bluegrass cultivars/seed lots $28 \mathrm{~d}$ after seeding in the growth chamber at $10 / 0{ }^{\circ} \mathrm{C}$ and on the "Tifdwarf" bermudagrass putting green following the 4 Jan. 1999 seeding date.

\begin{tabular}{lcc}
\hline \hline & \multicolumn{2}{c}{ Germination (\%) } \\
\cline { 2 - 3 } Cultivar & Growth chamber & Putting Green \\
\hline Colt & $68 \mathrm{a}^{z}$ & $34 \mathrm{a}$ \\
Cypress A & $62 \mathrm{ab}$ & $30 \mathrm{ab}$ \\
Cypress B & $43 \mathrm{de}$ & $20 \mathrm{ab}$ \\
Cypress C & $60 \mathrm{a}-\mathrm{c}$ & $28 \mathrm{ab}$ \\
Darkhorse & $63 \mathrm{ab}$ & $28 \mathrm{ab}$ \\
Laser A & $66 \mathrm{ab}$ & $29 \mathrm{ab}$ \\
Laser B & $59 \mathrm{a}-\mathrm{c}$ & $22 \mathrm{ab}$ \\
Winterplay A & $50 \mathrm{~cd}$ & $31 \mathrm{a}$ \\
Winterplay B & $36 \mathrm{e}$ & $14 \mathrm{~b}$ \\
Winterplay C & $55 \mathrm{bc}$ & $20 \mathrm{ab}$ \\
\hline
\end{tabular}

${ }^{2}$ Mean separation within columns by Duncan's multiple range test, $P \leq 0.05$ level. 
Budd, E.G. 1970. Seasonal germination patterns of Poa trivialis $\mathrm{L}$. and subsequent plant behavior. Weed Sci. 10:243-249.

Delouche, J.C. 1958. Germination of Kentucky bluegrass harvested at different stages of maturity. Proc. Assn. Offic. Seed Analysts 48:81-84.

Dudeck, A.E. and L.B. McCarty. 1989. Comparision of overseeded grasses for putting greens. Proc. Fla. State Hort. Soc. 102:127-133

Edminster, C.W. 1992. The Poa trivialis challenge. Landscape Mgt. 31(2):68, 70.

Froud-Williams, R.J., J.R. Hilton, and J. Dixon. 1986. Evidence for an endogenous cycle of dormancy in dry stored seeds of Poa trivialis L. New Phytol. 102:123-131.

Hurley, R.H. and C.R. Funk. 1985. Genetic variability in disease reaction, turf quality, leaf color, leaf texture, plant density, and seed shattering of selected genotypes of Poa trivialis, p. 221-226. In: Proc. of the $5^{\text {th }}$ Intl. Turfgrass Res. Conf. July 1985.

Johnson, B.J. 1988. Effects of pronamide on spring transition of a bermudagrass (Cynodon dactylon) green overseeded with perennial ryegrass (Lolium perenne). Weed Technol. 4:322-326.

Johnson, B.J. 1994. Fenarimol tolerance of roughstalk bluegrass overseeded in bermudagrass greens. Agron. J. 86:519-522.

Maguire, J.D. 1962. Speed of germination-Aid in selection and evaluation for seedling emergence and vigor. Crop Sci. 2:176-177.

Martin, B. 1996. Phytotoxic effects of some fungicides on Poa trivialis. Golf Course Mgt. 64(6):57-60.

Mazur, A.R. 1984. Chemical aids in winter overseeding. Carolina Nwsl. 20(2):20, 26.

McBee, G.C. 1967. Performance of certain coolseason grasses in overseeding studies on a Tifgreen bermudagrass golf green. Texas A\&M Univ., Texas Agr. Expt. Sta. Prog. Rpt. 2457.

Newell, A.J. and N.K. Bludau. 1993. Variation in total germination, rate of germination and seed weight among cultivars of Poa pratensis. J. Sports Turf Res. Inst. 69:83-89.
SAS Institute. 1985. SAS user's guide: Statistics. $5^{\text {th }}$ ed. SAS Inst., Cary, N.C.

Schmidt, R.E. and R.E. Blaser. 1961. Cool season grasses for winter turf on bermuda putting greens. U.S. Golf Assn. J. Turf Mgt. 14(5):25-29.

Schmidt, R.E. and J.F. Shoulders. 1980. Seasonal performance of selected temperate turfgrasses overseeded on bermudagrass turf for winter sports, p. 75-86. In: J.B. Beard (ed.). Proc. $3^{\text {rd }}$ Intl. Turf Res. Conf., Munich, Germany. 11-13 July 1977. Intl. Turfgrass Soc. and ASA, CSSA, and SSSA, Madison, Wis.

Ward, C.Y., E.L. McWhirter, and W.R. Thompson, Jr. 1974. Evaluation of cool-season turf species and planting techniques for overseeding bermudagrass golf greens, p. 480-495. In: E.C. Roberts (ed.). Proc. $2^{\text {nd }}$ Intl. Turfgrass Res. Conf., Blacksburg, Va. 19-21 June 1973. ASA and CSSA, Madison, Wis.

Williams E.D. 1983. Effects of temperature, light, nitrate and pre-chilling on seed germination of grassland plants. Ann. Appl. Biol. 103:161-172. 